\title{
The Legal Regulation of Hate Speech: The International and European Frameworks
}

\author{
NATALIE ALKIVIADOU \\ School of Law, University of Central Lancashire Cyprus
}

\begin{abstract}
Summary
This paper looks at the tools available on an international and European level in relation to the legal regulation of hate speech. More particularly, it considers the International Covenant on Civil and Political Rights and the International Convention on the Elimination of All Forms of Racial Discrimination along with related case-law of the respective monitoring committees. It looks at the European Convention on Human Rights and how the European Court of Human Rights interprets the limits of free speech when confronted with cases of hate speech. It also looks at the Framework Decision on Racism and Xenophobia of the European Union and the Additional Protocol to the Cybercrime Convention of the Council of Europe. Through the analysis it demonstrates that there is no common approach amongst international and European institutions on what hate speech is and the threshold which needs to be met for legal regulation to be permissible. It also demonstrates that the tools available focus only on some types of hate speech.
\end{abstract}

Keywords: Human Rights, Hate Speech, Homophobic Speech, Transphobic Speech, Racist Speech, Free Speech

\section{Introduction}

Hate speech is a threat to the proper functioning of a democratic society and a damning force to central values such as respect and solidarity. It "is speech that intentionally attacks a person or a group based on race, ethnicity, gender, disability, sexual orientation, religion, or any other prohibited criterion" (Tulkens, 2013: 3). It harms us on an interpersonal, community and societal level. In a world of rising right-wing populism and extremism, hate speech, as a by-product of such phenomena, needs seriously to be addressed. On an international and European level, the tools that have been developed to this end are mechanisms which directly prohibit 
certain types of speech. At the same time, international and European documents provide for the restriction of free speech if such speech, inter alia, violates the rights of others. The documents that will be discussed in this paper also include non-destruction clauses, an avenue which has been used predominantly by the European Court of Human Rights (ECtHR) to oust negationist and revisionist speech from Convention protection. This paper will assess the relevant provisions that exist on an international (United Nations (UN)) and European (European Union (EU) and Council of Europe) level to tackle hate speech. As a first step, the paper will elaborate on the definitional and contextual arena of hate speech and will proceed to look at the UN. In particular, it will analyse Article 4 of the International Convention on the Elimination of All Forms of Racial Discrimination (ICERD), which prohibits, amongst others, the dissemination of ideas of racial superiority. It will then assess Article 20(2) of the International Covenant on Civil and Political Rights (ICCPR) on the prohibition of any advocacy for religious, national, racial or religious hatred that constitutes incitement to discrimination, hostility or violence. As well as the substance of the aforementioned articles and the related jurisprudence of the Committee on the Elimination of Racial Discrimination (CERD) and the Human Rights Committee (HRC), the paper will also consider other documents such as General Recommendations and Concluding Observations. Following the UN framework, the paper will look at the Framework Decision on Combating Certain Forms and Expressions of Racism and Xenophobia by means of Criminal Law, which is the only legal tool existing on the EU level to tackle hate speech. As reflected in its title, it is limited to racist and xenophobic speech. The paper will subsequently consider the Council of Europe's Additional Protocol to the Convention on Cybercrime, Concerning the Criminalisation of Acts of a Racist and Xenophobic Nature Committed through Computer Systems as the only tool on this level to tackle hate speech directly, albeit only that appearing online. It will close with the key case-law of the ECtHR which sets out the position of the Court in interpreting the limits of Article 10 of the European Convention on Human Rights (ECHR) when such speech is deemed to be hate speech. One of the key premises, on which the analysis of the above will be effectuated, is that all relevant hate speech legislation available on the abovementioned levels is inherently flawed due to what can be referred to as the hierarchy of hate resulting from the prohibition of certain types of hate speech, for example racist speech, but not others, such as homophobic speech.

\section{Hate Speech: Definitional and Conceptual Framework}

There is no universally accepted definition of hate speech whilst the phenomenon is seldom defined by States or international institutions in legal documents. The closest we usually get is finding a definition in a non-binding policy document of a 
specialised committee or body. As well as not having a universally accepted definition, States and institutions around the globe adopt differing conceptualisations of (i) hate speech (McGonagle, 2013: 3) and (ii) free speech and its limitations. As noted in the 2017 Motion for European Parliament resolution on establishing a common legal definition of hate speech in the EU, the end product is that, even within a supranational organisation such as the EU, States adopt their own understanding and approaches to hate speech and how to tackle it. ${ }^{1}$

On the European level, the Council of Europe's Committee of Ministers developed one of the only documents, albeit non-binding, which seeks to shed light on the meaning of hate speech, namely, the 1997 Recommendation of the Council of Europe Committee of Ministers on Hate Speech. It holds that hate speech "is to be understood as covering all forms of expression which spread, incite, promote or justify racial hatred, xenophobia, anti-Semitism or other forms of hatred based on intolerance, including intolerant expression by aggressive nationalism and ethnocentrism, discrimination and hostility against minorities, migrants and people of immigrant origin". ${ }^{2}$ This definition is both interesting and problematic. Firstly, by including the justification of hatred in the sphere of prohibited speech, the Recommendation is broad in its conceptualisation of hate speech, encapsulating a low threshold. Secondly, the Recommendation blatantly disregards hate speech which is not linked to racial or religious groups and, as such, homophobic and transphobic speech is left outside the spectrum.

On a judicial level, the ECtHR has not, per se, provided a definition of hate speech. Instead, as in Gündüz v. Turkey (2003), it correlated hate speech with "all forms of expression which spread, incite, promote or justify hatred based on intolerance including religious intolerance". Interestingly, in Vejdeland and Others $v$. Sweden (2012), the ECtHR mobilised on the opportunity to rectify loopholes left by institutions such as the Council of Ministers, referred to above, in relation to homophobic speech, and argued that homophobic speech should be prohibited in the same manner as racist speech, stressing that "discrimination based on sexual orientation is as serious as discrimination based on race, origin or colour". ${ }^{4}$ In the same case, the Court offered an important insight into threshold issues. More particularly,

1 European Parliament: Motion for a European Parliament resolution on establishing a common legal definition of hate speech in the EU <http:/www.europarl.europa.eu/sides/getDoc. do?pubRef=-//EP//TEXT+MOTION+B8-2017-0172+0+DOC+XML+V0//EN $>\quad($ accessed 22 December 2017).

2 Council of Europe's Committee of Ministers Recommendation 97 (20) on Hate Speech.

3 Gündüz v. Turkey, App. no 35071/97 (ECtHR, 4 December 2003), para. 40, Erbakan v. Turkey, App. no. 59405/00 (6 July 2006), para. 56.

4 Vejdeland and Others v. Sweden, App. no. 1813/07 (ECtHR, 9 February 2012), para. 55. 
it held that it is not necessary for speech "to directly recommend individuals to commit hateful acts" given that harm may arise from "insulting, holding up to ridicule or slandering specific groups of the population". ${ }^{6}$ This is undoubtedly a broad conceptualisation on what is to be considered prohibited speech as the requirement for incitement to hatred and conducting hateful acts does not need to arise from speech. Instead, the insult, ridicule or slander found in speech is, in itself, harmful. Notwithstanding the delineations and elucidations made by the ECtHR, the fact that it has not, as yet, offered a hate speech definition has been characterised as "unsatisfactory from the point of judicial interpretation, doctrinal development and general predictability and foreseeability" (McGonagle, 2013: 10).

The central tenet to the difficulty of defining and ensuring a collective approach to hate speech on an international level is the perceived fine line between free speech and hate speech. In fact, several of the reservations made to provisions of international documents such as Article 4 of the ICERD, which prohibits, amongst others, racist speech, is the free speech justification. For example, a plethora of States Parties have incorporated reservations to Article 4 on free speech grounds, an indicative example being France's reservation, which holds:

With regard to article 4, France wishes to make it clear that it interprets the reference made therein to the principles of the Universal Declaration of Human Rights and to the rights set forth in article 5 of the Convention as releasing the States Parties from the obligation to enact anti-discrimination legislation which is incompatible with the freedoms of opinion and expression and of peaceful assembly and association guaranteed by those texts.

The CERD has repeatedly underlined the significance of prohibiting hate speech, noting that free speech "carries special duties and responsibilities, among which is the obligation not to disseminate racist ideas". ${ }^{7}$ This was noted, inter alia, in its 2011 Concluding Observations to the USA. Moreover, in its General Recommendation 15 on Measures to Eradicate Incitement to or Acts of Discrimination (1994), the CERD highlighted that "the prohibition of the dissemination of all ideas based upon racial superiority or hatred is compatible with the right to freedom of opinion and expression". ${ }^{8}$ However, this position is of no substantial assistance as it is not accompanied by any conceptual, contextual or theoretical analysis of free speech and hate speech and can, at its best, offer solely (empty) rhetorical value to

${ }^{5}$ Ibid., para. 54.

${ }^{6}$ Ibid.

${ }^{7}$ CERD Concluding Observations: United States of America (2001) CERD/C/59/Misc. 17/ Rev. 3, para. 12.

${ }^{8}$ CERD General Recommendation 15: Measures to Eradicate Incitement to or Acts of Discrimination (1994) A/48/18 at 114, para. 4. 
the deep-rooted issues related to hate speech regulation. The readiness of the CERD to restrict free speech in the name of protecting the rights and freedoms of others, in the sphere of regulating hatred, was also reflected in The Jewish community of Oslo et al. v. Norway (2005), which involved a march commemorating Rudolf Hess, in which it considered what is meant by the "due regard clause" of Article 4. More particularly, the prohibition of racist speech and activity, as incorporated in Article 4 and discussed in more detail below, should have "due regard of the Universal Declaration of Human Rights and the rights expressly set forth in article 5 of this Convention" which include, amongst others, the freedom of expression. In this case, the CERD held that "to give the right to freedom of speech a more limited role in the context of Article 4 does not deprive the due regard clause of significant meaning, all the more so since all international instruments that guarantee freedom of expression provide for the possibility, under certain circumstances, of limiting the exercise of this right". ${ }^{9}$ In fact, the Committee held that the "freedom of speech has been afforded a lower level of protection in cases of racist and hate speech dealt with by other international bodies". ${ }^{10}$ This is in line with its position that the due regard clause cannot be exploited for "cancelling or justifying a departure from the mandatory obligations set forth in Articles 4(a) and 4(b)". ${ }^{11}$

The conflict between free speech and hate speech is also demonstrated within the sphere of Article 19 of the ICCPR, which provides for the freedom of expression. Whilst the right to hold opinions is absolute, the freedom of expression "carries with it special duties and responsibilities" and can be restricted if this is provided for by law and is necessary for respect of the rights or reputations of others or for the protection of national security, public order or of public health or morals. ${ }^{12}$ In this realm, the HRC has been faced with cases involving hate speech. One example is Faurisson v. France (1996), which was brought by a revisionist who, inter alia, made claims such as the following:

I would wish to see that 100 per cent of all French citizens realize that the myth of the gas chambers is a dishonest fabrication ('est une gredinerie'), endorsed by the victorious powers of Nuremberg in 1945-46 and officialized on 14 July 1990 by the current French Government, with the approval of the court historians. ${ }^{13}$

9 The Jewish community of Oslo et al. v. Norway (15 August 2005), Communication no. 30/2003 (CERD/C/67/D/30/2003), para. 10.3.

10 Ibid., para. 10.5 .

${ }^{11}$ Committee on the Elimination of Racial Discrimination, $18^{\text {th }}$ Sess. (339 $\mathrm{mtg}$ ). at 152 , CERD/C/SR.399 (1978), para. 2.

12 Article 19 ICCPR.

13 Faurisson v. France, Communication no. 550/1993 (8 November 1996) CCPR/C/58/D/550/ 1993, para. 2.6. 
The historian who was prosecuted under an anti-revisionist law (the Gayssot Act) brought his case to the Committee, claiming that his freedom of expression had been violated. The Committee found that anti-Semitic speech could be restricted in order to protect the rights and freedoms of others, namely Jews, from religious hatred. More particularly, it held that:

The restrictions placed on the author did not curb the core of his right to freedom of expression, nor did they in any way affect his freedom of research; they were intimately linked to the value they were meant to protect - the right to be free from incitement to racism or anti-semitism; protecting that value could not have been achieved in the circumstances by less drastic means. ${ }^{14}$

The above overview demonstrates several significant issues. Firstly, it appears that at the heart of the problem in defining hate speech is the perceived tension between free speech and hate speech. Apart from one faulty example set by the Council of Europe's Committee of Ministers, no other body or committee of an institution whose outputs are binding or semi-binding or, at least, of some force at all, has formulated a definition of hate speech. For example, General Recommendation 15 of the CERD on Article 4 of the Convention, which deals with racist speech, amongst others, offers no definition of what this speech is. The CERD's General Recommendation 35 of Combatting Racist Hate Speech looks at several related issues such as what factors are considered for criminalisation and that whilst incitement is defined, racist hate speech is not. In fact, this recommendation recognises that the lack of a definition of hate speech in the Convention has "not impeded the Committee from identifying and naming hate speech phenomena and exploring the relationship between speech practices and the standards of the Convention". ${ }^{15}$ The closest the Recommendation gets to extrapolation is its remark that:

Racist hate speech can take many forms and is not confined to explicitly racial remarks. As is the case with discrimination under Article 1, speech attacking particular racial or ethnic groups may employ indirect language in order to disguise its targets and objectives. ${ }^{16}$

Although not a definition, this remark is reflective of the low threshold and broad spectrum of speech granted by the committee. Unlike, for example, the EU, which, in its Framework Decision on Racism and Xenophobia (2008), conceptu-

\footnotetext{
14 Ibid.

15 CERD General Recommendation 35: Combatting Racist Hate Speech (2013) CERD/C/ GC/35, para. 5 .

16 Ibid., para. 7.
} 
alises prohibited speech as speech which publicly calls for violence or hatred, ${ }^{17}$ the UN considers that even speech which, in a disguise, seeks to perpetuate hatred is to be prohibited.

In terms of a definition, neither the ICERD nor its monitoring committee offer a definition of racist speech in order to facilitate the Committee itself or the States Parties. Either way, even if a definition were provided for by this committee, it would be limited to racist speech. Furthermore, the regional court itself, which is directly relevant to the current discussion, namely the ECtHR, has dealt with several hate speech cases but has tiptoed around the definitional framework of the phenomenon. The result is that, in essence, "hate speech seems to be whatever people choose it to mean" (Kiska, 2012: 110) and, although States receive guidelines from institutions, such as the CERD, to prohibit the dissemination of racist ideas and racist expression, there is no technical analysis of themes such as thresholds and delineations between potentially conflicting freedoms such as expression and nondiscrimination.

\section{Article 4 of the ICERD: Prohibiting the Manifestation of Racism}

Article 4 of the ICERD encapsulates the prohibition of racist ideas, propaganda and expression as well as racist acts of violence and incitement to such acts. It seeks to tackle racial hatred as manifested both by speech, acts and organised groups and racist speech uttered by public officials. In its General Recommendation 35, the CERD noted that speech and acts prohibited under this article are those which are:

directed against groups recognized in Article 1 of the Convention - which forbids discrimination on grounds of race, colour, descent, or national or ethnic origin - such as indigenous peoples, descent-based groups, and immigrants or noncitizens, including migrant domestic workers, refugees and asylum seekers, as well as speech directed against women members of these and other vulnerable groups... The Committee's attention has also been engaged by hate speech targeting persons belonging to certain ethnic groups who profess or practice a religion different from the majority, including expressions of Islamophobia, anti-Semitism and other similar manifestations of hatred against ethno-religious groups... ${ }^{18}$

The historical context of the ICERD is significant in contextualizing and comprehending the formulation of Article 4. As noted by the CERD in its General Re-

17 Article 1(a) of the Framework Decision on Racism and Xenophobia: (a) publicly inciting to violence or hatred directed against a group of persons or a member of such a group defined by reference to race, colour, religion, descent or national or ethnic origin.

18 CERD General recommendation 35: Combatting Racist Hate Speech (2013) CERD/C/ GC/35, para. 6 . 
commendation 15, at that time "there was a widespread fear of the revival of authoritarian ideologies", ${ }^{19}$ and the need to militantly restrict expression and association of racists was considered paramount, hence the existence of Article 4. In General Recommendation 15, the CERD highlighted that this article is of a mandatory character and has been described by Mahalic and Mahalic (1987) as "the most important article in the Convention". ${ }^{20}$ It is particularly relevant to the current discussion since, as noted by the CERD in General Recommendation 35, it has "functioned as the principal vehicle for combatting hate speech". ${ }^{21}$ In the current global context of rising far-right ideologies, this article is not one to be forgotten, either by States themselves or by institutions. The text of Article 4 reads as follows:

States Parties condemn all propaganda and all organizations which are based on ideas or theories of superiority of one race or group of persons of one colour or ethnic origin, or which attempt to justify or promote racial hatred and discrimination in any form, and undertake to adopt immediate and positive measures designed to eradicate all incitement to, or acts of, such discrimination and, to this end, with due regard to the principles embodied in the Universal Declaration of Human Rights and the rights expressly set forth in Article 5 of this Convention, inter alia:

(a) Shall declare an offence punishable by law all dissemination of ideas based on racial superiority or hatred, incitement to racial discrimination, as well as all acts of violence or incitement to such acts against any race or group of persons of another colour or ethnic origin, and also the provision of any assistance to racist activities, including the financing thereof;

(b) Shall declare illegal and prohibit organizations, and also organized and all other propaganda activities, which promote and incite racial discrimination, and shall recognize participation in such organizations or activities as an offence punishable by law;

(c) Shall not permit public authorities or public institutions, national or local, to promote or incite racial discrimination.

In its Resolution 66/143, the UN General Assembly has reiterated the importance of States Parties taking the necessary measures to tackle the different forms

19 CERD General Recommendation 15: Measures to Eradicate Incitement to or Acts of Discrimination (1994) A/48/18 at 114, para. 1.

${ }^{20}$ Drew Mahalic \& Joan Gambee Mahalic, The Limitation Provisions of the International Convention on the Elimination of All Forms of Racial Discrimination (1987) Human Rights Quarterly 1,89 .

${ }^{21}$ CERD General Recommendation 35: Combatting Racist Hate Speech (2013) CERD/C/ $\mathrm{GC} / 35$, para. 8 . 
and manifestations of racism, as extrapolated in this Article, ${ }^{22}$ whilst in Resolution 16/18, the UN Human Rights Council highlighted that States Parties must criminalize the incitement to imminent violence based on religion or belief. ${ }^{23}$ From the very beginning of its activities, since General Recommendation 1 on States Parties' Obligations, the CERD has underlined that the incorporation of Article 4 into national legislation is "obligatory under the Convention for all States Parties"24 and damns countries which do not comply with this strict requirement. ${ }^{25}$ Although the development of relevant legislation is an obligation to acceding States Parties, the CERD has highlighted that enacting legislation is not sufficient for purposes of Article 4 compliance and that the proper implementation of such legislation is a necessary pre-requisite. ${ }^{26}$ For example, in cases such as Gelle v. Denmark (2006), Jama v. Denmark (2009), Adan v. Denmark (2010) and TBB-Turkish Union v. Germany (2013), the CERD highlighted that:

It does not suffice, for the purposes of Article 4 of the Convention, merely to declare acts of racial discrimination punishable on paper. Rather, criminal laws and other legal provisions prohibiting racial discrimination must also be effectively implemented by the competent national tribunals and other State institutions. This obligation is implicit in Article 4 of the Convention. ${ }^{27}$

Article 4 provides that States must take immediate and positive measures in order to meet the requirements of this article. For elucidation purposes, such measures were defined by the Committee in General Recommendation 32 on the Meaning and Scope of Special Measures in the Convention (2009) as a comparison of "legislative, executive, administrative, budgetary and regulatory instruments... as well

${ }^{22}$ General Assembly Resolution 66/143: Inadmissibility of certain practices that contribute to fuelling contemporary forms of racism, racial discrimination, xenophobia and related intolerance (29 March 2012).

${ }^{23}$ Human Rights Council Resolution 16/18: Combating intolerance, negative stereotyping and stigmatization of, and discrimination, incitement to violence, and violence against persons based on religion or belief (12 April 2011), Human Rights Council Resolution 19/25: Combating intolerance, negative stereotyping and stigmatization of, and discrimination and incitement to violence and violence against persons based on religion or belief (10 April 2012).

24 CERD General Recommendation 1: States Parties' Obligations (1972) A/8718 at 37.

25 See, inter alia, Concluding Observations: Japan, CERD, CERD/C/JPN/CO/7-9 (2014), para. 10.

26 CERD General Recommendation 15: Measures to Eradicate Incitement to or Acts of Discrimination, A/48/18 at 114 (1994), para. 2.

27 Gelle v. Denmark, Communication no. 34/2004 (15 March 2006) CERD/C/68/D/34/2004, para. 7.3. This was reiterated in Jama v. Denmark, Adan v. Denmark and TBB-Turkish Union v. Germany. 
as plans, policies, programmes and... regimes". Furthermore, in the framework of speech potentially leading to violence and, more particularly, threats of racial violence, the Committee highlighted the strict duty on authorities to investigate such threats swiftly and effectively. More particularly, in L.K. v. the Netherlands (1991) the CERD noted that "when threats of racial violence are made, and especially when they are made in public and by a group, it is incumbent upon the State to investigate with due diligence and expedition". ${ }^{28}$

In relation to the actual handling of prohibited speech and acts under Article 4, the CERD has not been clear. For example, in its General Recommendation 31 on the Prevention of Racial Discrimination in the Administration and Functioning of the Criminal Justice System, it was held that "States parties should fully comply with the requirements of Article 4 of the Convention and criminalize all acts of racism". ${ }^{29}$ However, in Yilmaz-Dogan v. The Netherlands (1988), which involved racist statements made by an employer, the CERD recognised that the importance of the expediency principle which is "the freedom to prosecute or not prosecute, is governed by considerations of public policy" 30 and held that the Convention "cannot be interpreted as challenging the raison d'etre of that principle". ${ }^{31}$ However, it underlined that the Convention is to be considered in all cases involving racial discrimination. ${ }^{32}$ In Zentralrat Deutscher Sinti und Roma et al. v. Germany (2008), the Committee found that the disciplinary procedures taken against the author of a racist letter were sufficient to meet the requirements of Article 4. So, on the one hand, the actual provision of Article 4 holds that States Parties "shall declare an offence punishable by law" 33 the dissemination of racist ideas and racist expression and General Recommendation 31 stipulates the requirement for criminal penalties. On the other hand, the Committee's jurisprudence has been flexible to allow less grave approaches to prohibited expression and conduct. Although less harsh "penalties" for racist speech could facilitate the use of Article 4 by States Parties, a clear line should be established and endorsed by the CERD.

In light of the above, Article 4 of the ICERD is undoubtedly significant for tackling racist speech (not hate speech in general). However, the issue that arises

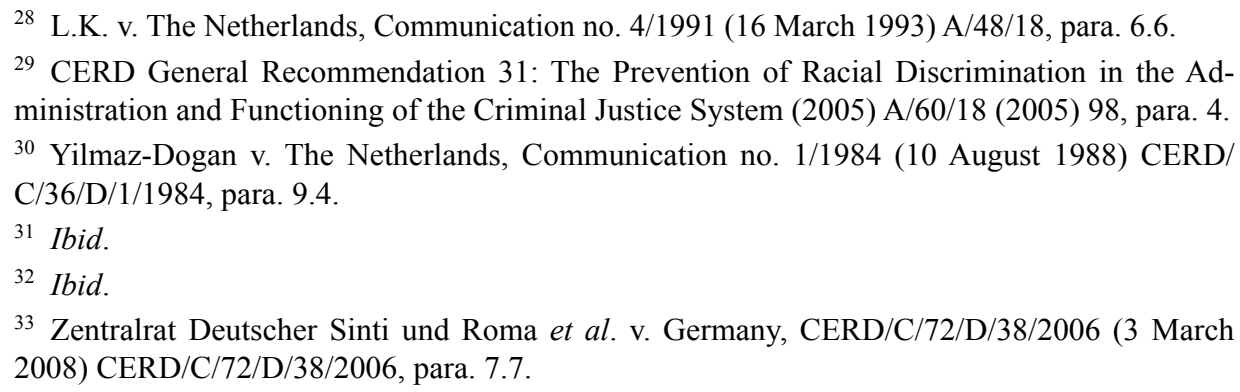
ministration and Functioning of the Criminal Justice System (2005) A/60/18 (2005) 98, para. 4.

30 Yilmaz-Dogan v. The Netherlands, Communication no. 1/1984 (10 August 1988) CERD/ C/36/D/1/1984, para. 9.4.

31 Ibid.

32 Ibid.

33 Zentralrat Deutscher Sinti und Roma et al. v. Germany, CERD/C/72/D/38/2006 (3 March 2008) CERD/C/72/D/38/2006, para. 7.7. 
is whether its significance is beyond conceptual. More particularly, nowhere in the article or in the convention itself or in any explanatory documents such as General Recommendations is there an analysis of what racist speech, a major element of this article, actually is, in both theoretical and practical terms. Further, fleeting references to the prohibition of "all dissemination of ideas based on racial superiority or hatred" are made in the article with no supporting extrapolation on semantics and notions. This is contrary to incitement, which, as discussed above, has been explained in General Recommendation 35, which held that:

Incitement characteristically seeks to influence others to engage in certain forms of conduct, including the commission of crime, through advocacy or threats. Incitement may be expressed or implied, through actions such as displays of racist symbols or distribution of materials as well as words. ${ }^{34}$

This extrapolation is a positive step to supporting countries in formulating and implementing necessary measures to tackle incitement as there is a conceptual explanation as well as practical examples on what kind of activities (for example, the display of racist symbols) can constitute this prohibited conduct. Such an explanation is particularly important for the prohibition of expression which is often contextualised by States Parties within a free speech prism, as can anyhow be discerned in the reservations imposed on this article on free speech grounds. ${ }^{35}$ Moreover, it is clearly evident that this article is not working. Had it been sincerely accepted by States Parties, violent neo-Nazi groups, such as Golden Dawn of Greece and Jobbik of Hungary, would not be prowling the streets and entering parliaments, and far-right populists around the globe would not be allowed to utter systematically racist rhetoric. Moreover, considering free speech considerations which have time and again been communicated by States Parties, the tilting of the CERD towards the actual criminalization of racist speech may constitute an obstacle in achieving the aims and objectives of the Convention, namely the elimination of all forms of racial discrimination. As well as taking that consideration into account, the other step that could be taken by the UN in facilitating the correct implementation of this article is the elucidation of prohibited conduct and the provision of a definitional framework in respect to racist speech.

${ }^{34}$ CERD General Recommendation 35: Combatting Racist Hate Speech (2013) CERD/C/ $\mathrm{GC} / 35$.

${ }^{35}$ For a full list of reservations, see: https://treaties.un.org/pages/ViewDetails.aspx?src=IND\& mtdsg_no=IV-2\&chapter=4\&lang=en (accessed 20 December 2017). 


\section{Article 20(2) of the ICCPR: Prohibiting Advocacy of Hatred}

Article 20(2) of the ICCPR is different to the majority of rights found in this Covenant and other conventions because, rather than providing a particular human right, as with most convention articles, it directly prohibits certain forms of expression. This is like Article 4 of the ICERD which, rather than setting out a particular human right, limits rights and freedoms for purposes of restricting the manifestation of racism. Article 20(2) stipulates that: "Any advocacy of national, racial or religious hatred that constitutes incitement to discrimination, hostility or violence shall be prohibited by law." Issues of free speech arise, just as in the case of Article 4 of the ICERD, since advocacy occurs through the vehicle of expression. Several countries have incorporated reservations to Article 20(2) on free speech grounds, an indicative example being the reservation of Luxembourg which held:

The Government of Luxembourg declares that it does not consider itself obligated to adopt legislation in the field covered by Article 20, paragraph 1, and that Article 20 as a whole will be implemented taking into account the rights to freedom of thought, religion, opinion, assembly and association laid down in Articles 18, 19 and 20 of the Universal Declaration of Human Rights and reaffirmed in Articles 18, 19, 21 and 22 of the Covenant.

To this end, the HRC has been very clear in its approach, just as it was in its Article 19 jurisprudence on hate speech, following the same line and path as the CERD. More particularly, in its General Comment 34 on Article 19 - Freedom of Opinion and Expression, the Human Rights Committee held that: "Articles 19 and 20 are compatible with and complement each other. The acts that are addressed in Article 20 are all subject to restriction pursuant to Article 19, paragraph 3." ${ }^{\prime 36}$

The 2012 Report of the Special Rapporteur on the Promotion and Protection of the Right to Freedom of Opinion and Expression defined advocacy as the "explicit, intentional, public and active support and promotion of hatred towards the target group" ${ }^{37}$ This report also provides a brief description of what is meant by hatred, incitement, discrimination, hostility and violence and, although it is beyond the scope of this paper to assess each term, the existence of such a report and this definitional framework is significant. More particularly, having such terms and extrapolations potentially facilitates the understanding of States Parties of the words and, therefore, the article, and could thus promote the correct use of Article 20(2) where relevant. However, the definitions, as with that of advocacy referred to above, are

${ }^{36}$ Human Rights Committee General Comment 34: Article 19 - Freedom of Opinion and Expression (2011) CCPR/C/GC/34, para. 50.

${ }^{37}$ Report of the Special Rapporteur on the Promotion and Protection of the Right to Freedom of Opinion and Expression (2012) A/67/357, para. 44(b). 
a brief overview of central elements rather than an exhaustive definition. As a result, and as can be determined by how "advocacy" is defined, problems still remain regarding the precise meaning and issues of threshold. For example, what is meant by active support? What threshold needs to be surpassed for such support to exist?

Beyond the threshold issue of the words of the article, the threshold of Article 20(2) more generally has been set out by the aforementioned Special Rapporteur and by the Rabat Plan of Action on the Prohibition of Advocacy of National, Racial or Religious Hatred that Constitutes Incitement to Discrimination, Hostility or Violence. The Special Rapporteur on the Promotion and Protection of the Right to Freedom of Opinion and Expression held that "the threshold of the types of expression that would fall under the provisions of Article 20 (2) should be high and solid". ${ }^{38}$ Furthermore, the Special Rapporteur noted that in determining the threshold, States Parties should adopt the test set out by the NGO Article 19. This test holds that States Parties must consider the "severity, intent, content, extent, likelihood or probability of harm occurring as well as the imminence and context of the speech in question". ${ }^{39}$ The Rabat Plan of Action states that it is a necessary pre-requisite that a high threshold is associated with the implementation of Article $20{ }^{40}$ General Comment 11 of the HRC on the Prohibition of Propaganda for War and Inciting National, Racial or Religious Hatred holds that, in order to meet the obligations of this article, States Parties must implement relevant legislation which directly prohibits the advocacy set out in Article 20(2). ${ }^{41}$ However, as determined by the NGO Article 19 in a study prepared for the regional expert meeting on Article 20, Article 20 is rarely enshrined in national legislation. ${ }^{42}$ The case of Mohamed Rabbae, A.B.S and N.A v. The Netherlands (2016) was brought against the Netherlands for the acquittal of Geert Wilders, leader of the Dutch Party for Freedom (Partij voor de Vrijheid) following his prosecution for racist statements. This is the only case-law of the HRC where there is a relatively in-depth extrapolation of the State obligations that amount from Article 20(2). The Committee held that Article 20(2):

38 Ibid., para. 45.

39 Ibid., para. 79.

40 Rabat Plan of Action on the Prohibition of Advocacy of National, Racial or Religious Hatred that constitutes Incitement to Discrimination, Hostility or Violence (2002), para. 22.

41 General Comment 11: Article 20 - Prohibition of Propaganda for War and Inciting National, Racial or Religious Hatred (1994), HRI/GEN/1/Rev.1 at 12, para. 1.

42 Article 19 - Towards an Interpretation of Article 20 of the ICCPR: Thresholds for the Prohibition of Incitement to Hatred (Work in Progress): A Study Prepared for the Regional Expert Meeting on Article 20, Organised by the Office of the High Commissioner for Human Rights, Vienna, February 8-9, 2010, p. 3 <http:/www.ohchr.org/Documents/Issues/Expression/ICCPR/Vienna/ CRP7Callamard.pdf $>$ (accessed 8 December 2017). 
does not merely impose a formal obligation on States Parties to adopt legislation prohibiting such conduct. Such a law would be ineffective without procedures for complaints and appropriate sanctions. ${ }^{43}$

This is the same position as that adopted by the CERD in relation to state obligations in the realm of Article 4 of the ICERD. Although Article 4 of the ICERD renders racist expression an "offence punishable by law", Article 20(2) solely requires the prohibition by law of such advocacy. To this end, the Committee noted in the case against Wilders that "Article 20(2) does not expressly require the imposition of criminal penalties, but instead requires that such advocacy be 'prohibited by law'. Such prohibitions may include civil and administrative as well as criminal penalties. ${ }^{\prime 44}$ In this case, the fact that the State Party had an established legislative framework that covered the obligations arising from Article 20(2), and given that the State Party pursued the prosecution of this case, meant that the Netherlands had not violated its obligations under Article 20(2). Importantly, the Committee set out that the obligation under this article:

does not extend to an obligation for the State Party to ensure that a person who is charged with inciting to discrimination, hostility or violence will invariably be convicted by an independent and impartial court of law. ${ }^{45}$

In brief, insofar as a functional legislative framework exists that is relied upon where relevant, the State Party is in conformity with its obligations. The issue of sanctioning bad speech is of direct relevance to the discussion on Article 20(2), but also on Article 4. It is clear that there is a general confusion within the UN as to what sanctions need to be imposed on such speech. This is reflected in the discrepancy arising from the wording of the two articles under consideration, with Article 4 of the ICERD referring to the prohibited conduct being "punishable by law" and Article 20(2) of the ICCPR referring to the advocacy being "prohibited by law" rather than punished. What is paradoxical is that while Article 4 prohibits the dissemination of racist ideas, Article 20(2) prohibits the advocacy for phenomena such as hatred and violence. Despite that, it is the former which is criminally punishable, based on the reading of the article, rather than the latter, notwithstanding the lower threshold of harm associated with Article 4.

Moreover, the terms "punishable" and "prohibited", although indicative of the criminal or non-criminal nature of a penalty, do not go far in designating what kind

43 Vassilari, Maria et al. v. Greece (19 March 2009), Communication no. 570/2007, J.R.T and the W.G. Party v. Canada (6 April 1983), Communication no. 104/1981.

44 Mohamed Rabbae, A.B.S and N.A v. The Netherlands (14 July 2016), Communication no. 2124/2011, para. 10.4 .

45 Ibid., para. 10.7. 
of repercussion haters should have in law. To complicate things further, in his 2012 report, when assessing Article 20(2), the Special Rapporteur on the Freedom of Opinion and Expression noted that "there is no requirement to criminalize such expression" 46 while the Rabat Plan of Action noted that "criminal sanctions related to unlawful forms of expression should be seen as last resort measures" ${ }^{47}$ Ensuring a commonly adhered to approach amongst UN bodies would be the first step to directing States Parties correctly as to how speech that falls within the realm of the above articles is dealt with. Therefore, although conceptually significant as a tool to tackle hate speech, Article 20(2) is seldom found in national legislation. Further, the lack of clarity of the practical meaning of terms particularly in terms of thresholds, regardless of the effort made by the Special Rapporteur to elucidate the notions, in addition to the limited amount of HRC jurisprudence tackling this article, means that there continue to be obstacles in its actual use.

\section{The UN Framework and the Hierarchy of Hate: A Major Thorn in its Side}

Therefore, the two mechanisms that exist on the UN level to tackle hate speech are Article 4 of the ICERD and Article 20(2) of the ICCPR. These articles cover hatred that attacks ethnic, racial and religious characteristics. There are no equivalent conventions or articles which seek to protect victims who are targeted due to other characteristics such as sexual orientation and gender identity. This is a major downfall in the UN framework and sets a distressing precedent for States Parties, essentially indicating that steps do not have to be taken to punish or prohibit homophobic or transphobic speech. Regarding this, in its 2013 Policy Brief on Hate Speech against LGBTI people, the NGO Article 19 has argued that Article 20(2) of the ICCPR must be read in light of the characteristics set out in Article 2 of the ICCPR which include sex and "other status" ${ }^{48}$ Although no reference is made in Article 2 of sexual orientation and "gender identity", they could be incorporated in "other status" and as held by the HRC in Toonen v. Australia (1992), "sex" must include sexual orientation. ${ }^{49}$ However, a recommendation of an NGO in how the Covenant should be interpreted is by far insufficient to provide protection against homophobic speech, whilst no respective recommendation has been made in relation to transphobic speech. Essentially, the UN framework has completely disregarded

46 Report of the Special Rapporteur on the Promotion and Protection of the Right to Freedom of Opinion and Expression (2012) A/67/357, para. 47.

47 Rabat Plan of Action on the Prohibition of Advocacy of National, Racial or Religious Hatred that constitutes Incitement to Discrimination, Hostility or Violence (2002), para. 22.

48 ARTICLE 19, "Policy Brief - Responding to Hate Speech against LBGTI People" (2013) 12.

49 Toonen v. Australia, Communication No. 488/1992, U.N. Doc CCPR/C/50/D/488/1992 (1994), para. 8.7. 
characteristics that are vulnerable to haters beyond the ones described above, establishing, therefore, a hierarchy of importance when it comes to what ought to be protected and what not.

\section{The European Union's Framework Decision on Combating Certain Forms and Expressions of Racism and Xenophobia by means of Criminal Law}

Following seven years of negotiation, ${ }^{50}$ the EU developed the Framework Decision on Combatting Racism and Xenophobia through Criminal Law. This document seeks to tackle the phenomena of racism and xenophobia as manifested, inter alia, through hate speech, endorsing criminal law as the only tool. As such, this is not a mechanism to tackle hate speech in its entirety but, rather, one that also deals with racist and xenophobic speech. As could be expected, given the use of criminal law, the threshold necessary for speech to be considered hate speech in the context of this document is high and definitely higher than those existing on either of the tools available at the UN level. Moreover, the uniform application across EU Member States of this Framework Decision is problematic, if not impossible, due to the incoherence in countries' approaches to the meaning of hate speech, the limits of free speech and the way in which hate speech should be tackled. The European Parliament has picked up on this reality and, in 2017, called for a resolution on establishing a common legal definition of hate speech in the EU. ${ }^{51}$ To perplex matters further, the Framework Decision itself does not provide for a definition of hate speech. Instead, Article 1 entitled "offences concerning racism and xenophobia" holds that each Member State shall punish the intentional conduct of "publicly inciting to violence or hatred directed against a group of persons or a member of such a group defined by reference to race, colour, religion, descent or national or ethnic origin".

A few points can be taken from this article. Firstly, intention is necessary and the punishable conduct must be public. Furthermore, the speech must amount to incitement. It is not sufficient that there is a mere dissemination of ideas as is the case with Article 4 of the ICERD. Unlike Article 20(2) of the ICCPR, which prohibits incitement to, inter alia, discrimination, this document restricts itself solely to prohi-

50 European Commission. 2014. Report from the Commission to the European Parliament and the Council on the Implementation of Council Framework Decision 2008/913/JHA on combating certain forms and expressions of racism and xenophobia by means of criminal law. European Commission report, http://eur-lex.europa.eu/legal-content/EN/TXT/?uri=celex:52014DC0027 (accessed 16 February 2018).

51 European Parliament. 2017. Motion for a European Parliament resolution on establishing a common legal definition of hate speech in the EU. European Parliament document, http://www. europarl.europa.eu/sides/getDoc.do?pubRef=-//EP//TEXT+MOTION+B8-2017-0172+0+DOC $+\mathrm{XML}+\mathrm{V0} / / \mathrm{EN}$ (accessed 12 August 2017). 
bit incitement to violence or hatred, thereby automatically heightening the threshold of punishable conduct. At first sight, one may consider this to be logical given that the tool which is used in the Framework Decision is the most restrictive of all and, as such, the threshold must be sufficiently high. However, if one turns to the position of the UN's CERD, discussed above, it requires that, for purposes of Article 4, States must ensure the adequate implementation of "criminal laws and other legal provisions prohibiting racial discrimination". ${ }^{52}$ Therefore, it is either the case of the UN adopting a very low threshold of what constitutes hate speech, even when criminal law is to be utilised, or that the EU has gone too far in threshold requirements because criminal law is utilised. Unfortunately, the EU did not take any steps to develop, either within this Framework Decision or elsewhere, the possibility for other tools to be used by Member States to tackle hate speech that could emanate from civil law, and, therefore, have lower speech threshold requirements due to the severity of its consequence. In addition, as with all other tools that are examined in this paper, the speech must be racist or xenophobic, with the EU disregarding other significant phenomena in this document such as homophobia and transphobia and, as such, their byproducts such as hate speech emanating therefrom. As well as the public incitement to hatred and violence, this article prohibits publicly condoning, denying or grossly trivializing certain international crimes directed at particular groups, insofar as this conduct occurs in a manner likely to incite to violence or hatred against such a group or a member of such a group. With a view to satisfy States with strict free speech traditions, Article 1(2) provides that the above-outlined conduct can be deemed punishable only if it is carried out in a manner likely to disturb public order or which is threatening, abusive or insulting, thereby giving the possibility to Member States to heighten the threshold even further. Whilst the intention of the drafters is clear, namely to satisfy the requirements of Member States with free speech concerns, it could also be argued that these safety nets are, in fact, futile since the punishable conduct per se could be considered to disturb public order (particularly since incitement needs to be public, hateful and/or violent). Moreover, conduct which publicly seeks to advance violence or hatred against a particular group could automatically tick the boxes of abusive or insulting and, potentially, the box of threatening. To protect free speech considerations further in relation to revisionist and negationist speech, Article 1(4) provides that States can only punish the denial of international crimes, which have been established by the decision of a national and/or international court.

52 Gelle v. Denmark, Communication no. 34/2004 (15 March 2006) CERD/C/68/D/34/2004, para. 7.3. This was reiterated in Jama v. Denmark, Adan v. Denmark and TBB-Turkish Union v. Germany. 
In sum, this document deals with racism and xenophobia and its by-products, one of them being racist and xenophobic speech. It endorses a higher threshold of punishable speech in comparison to Article 4 of the ICERD and Article 20(2) of the ICCPR and only punishes speech which targets members of a group characterized by its race, colour, religion, descent or national or ethnic origin and, as such, only criminalizing certain types of hate speech. The European Parliament has recognised this issue and in its 2014 Roadmap against Homophobia and Discrimination on Grounds of Sexual Orientation and Gender Identity recommended that the Commission propose a "recast" of the Framework Decision to include "other forms of bias crime and incitement to hatred, including on grounds of sexual orientation and gender identity". ${ }^{53}$ Unfortunately, the flawed nature of the Framework Decision has been fed into the Code of Conduct on Countering Illegal Hate Speech Online as it constitutes its conceptual foundation. The Code of Conduct imposes, inter alia, the duty on the signatory IT companies to remove reported hate speech, which it deems to be such, from their platforms within 24 hours.

\section{The Additional Protocol to the Cybercrime Convention Concerning the Criminalisation of Acts of a Racist and Xenophobic Nature Committed through Computer Systems}

The Cybercrime Convention tackles crimes occurring through computer systems and has been ratified by Council of Europe States as well as others such as the USA. As underlined by Banks (2010: 236), due to First Amendment concerns, the USA only agreed to ratify the Convention after the issue of the criminalization of online racist and xenophobic speech was removed from discussions. As such, to tackle racist and xenophobic speech disseminated through computer systems, the Council of Europe drafted the Additional Protocol to compensate for the gap created. This came into force in 2006. Article 2 therein defines racist and xenophobic material as:

Any written material, any image or any other representation of ideas or theories, which advocates, promotes or incites hatred, discrimination or violence, against any individual or group of individuals, based on race, colour, descent or national or ethnic origin, as well as religion if used as a pretext for any of these factors.

In terms of thresholds, this definition adopts a similar approach to Article 20(2) of the ICCPR, incorporating, unlike the EU's Framework Decision, which came a couple of years later, discrimination as well as hatred or violence. Interestingly though, Article 3(2) provides parties with the right not to attach criminal liability to such conduct if the material, although advocating, promoting or inciting discrimina-

53 European Parliament Resolution of 4 February 2014 on the EU Roadmap against homophobia and discrimination on grounds of sexual orientation and gender identity (2013/2183(INI)). 
tion, is not associated with hatred or violence. Although this possibility exists only if other effective remedies are available, it nevertheless waters down the relevance of discrimination in this sphere. The role of discrimination as something to be prohibited is further restricted with part 3 of the same article which absolutely exempts States from criminalizing this if their legal systems are free speech protectors. In line with the aims of the Additional Protocol, which are to tackle racism and xenophobia, material should be targeted at one of the groups that we have seen in the other documents, such as ethnic and religious groups but not others such as sexual minorities. Although these groups fall within the framework of the Protocol's aims, there is no logical legal or social reasoning as to why the Council of Europe opted to focus only on racism and xenophobia and not on other types of intolerance that appear and are promoted through computer systems. Article 3 imposes the duty on States to criminalize the public, intentional and "without right" dissemination of racist and xenophobic material, with the exemptions discussed above. Article 5 deals with racist and xenophobic insults which occur publicly, intentionally and "without right". A State may require that the insult subsequently exposed a person to, inter alia, hatred, contempt or ridicule. If this safety net is not sufficient for free speech concerns or any other relevant concerns, Article 5 can be applied only in part or not applied at all. Article 4, dealing with threats, removes the need for the conduct to be public but still incorporates the condition that such threats occur without right. In a nutshell, a user can disseminate racist material or insult someone because of his or her ethnic group, so long as this happens in a private chat and so long as this does not amount to a threat. As noted by the Protocol's Explanatory Note, all acts, minus insults, must be public to protect Article 8 of the ECHR. ${ }^{54} \mathrm{~A}$ rather bizarre condition is that racist threats must be happening "without right", with the opposite scenario, namely racist and xenophobic threats rightfully being uttered is hard to legally conceptualise given that threats, regardless of motive, anyhow fall within a non-righteous framework. Article 6 deals with the denial, gross minimization, approval or justification of genocide or crimes against humanity, which come along with safeguards such as those subsequently found in the EU's Framework Decision. For example, that such conduct is committed with the intent to incite hatred against a group of people based on their ethnic origin whilst States have the right not to apply this part in whole or in part.

\section{Hate Speech: The Position of the European Court of Human Rights}

Article 10 of the ECHR provides for free opinion and speech, a freedom which carries "duties and responsibilities" and which may be subject to limitations in order

${ }^{54}$ Explanatory Report to the Additional Protocol to the Convention on Cybercrime, Concerning the Criminalisation of Acts of a Racist and Xenophobic Nature Committed through Computer Systems, para. 29. 
to, inter alia, protect the reputation or rights of others. The ECHR does not incorporate a provision like Article 20(2) of the ICCPR and, as such, there is no positive obligation on Contracting States to develop legislation or other tools to prohibit hate speech. However, under Article 10, the Court has dealt with free speech allegations by individuals and groups found guilty of hate speech in their own countries. In addition, Article 17 of the ECHR, the non-destruction clause, has been invoked in relation to revisionist and negationist speech and in one case involving expression targeted against Muslims. Although no mechanisms exist to tackle hate speech under the Convention, a discussion on the ECtHR jurisprudence is relevant to any discussion on the international and European regulatory frameworks vis-à-vis hate speech as this allows for the establishment of the Court's position on hate speech. The ECtHR has not offered a definition of hate speech, but has limited itself to referring to the aforementioned Recommendation of the Council of Europe Committee of Ministers in some cases such as Balsyte-Lideikiene v. Lithuania. ${ }^{55}$ However, it has conceptualised on issues of threshold and substance of hate speech discussed below. It is noteworthy that "the Court has often shown itself to be a house divided when it comes to freedom of expression" (Buyse, 2014: 492). The below jurisprudential analysis is non-exhaustive, but, rather, the major relevant cases have been selected so as to demonstrate the Court's approach.

In the case of Féret v. Belgium (2009) the applicant who was the chairman of the political party "Front National" was editor in chief of the party's publication and owner of its website. He was convicted in Belgium for publicly inciting discrimination or hatred through the leaflets disseminated for the party's election campaign. Statements on these leaflets included "Stop the Islamisation of Belgium" and "Save our people from the risk posed by Islam the conqueror". The Court found that the criminal proceedings brought against the application did not violate Article 10 of the ECHR on the grounds that limiting this type of speech is necessary to satisfy some of the limitation grounds of part 2 of the article, namely the protection of the rights and freedoms of others and to prevent public disorder. The Court underlined that politicians have a particular duty in promoting democracy and its principles and drew attention to the impact of the impugned expression on social cohesion and public order. More particularly, it held that:

insults, ridicule or defamation aimed at specific population groups or incitation to discrimination, as in this case, sufficed for the authorities to give priority to fighting hate speech when confronted by the irresponsible use of freedom of expression which undermined people's dignity, or even their safety. ${ }^{56}$

55 Council of Europe's Committee of Ministers Recommendation 97 (20) on Hate Speech (30 October 1997).

${ }^{56}$ Féret v. Belgium, App. no. 15615/07, (ECHR, 16 July 2009), para. 73. 
In reaching its judgement, the Court also conducted a social appraisal of the impact of racist and xenophobic expression finding that statements were "inevitably of such a nature as to arouse, particularly among the less informed members of the public, feelings of distrust, rejection or hatred towards foreigners". ${ }^{57}$

A parallel approach was adopted by the Court in Le Pen v. France (2010), in which the ECtHR dealt with an application by Le Pen of the French National Front for the alleged breach of Article 10 as a result of his conviction for inciting hatred against Muslims during an interview he gave to Le Monde newspaper. In this interview, he held that "when I tell people that when we have 25 million Muslims in France we French will have to watch our step, they often reply: 'But Le Pen, that is already the case now!' - and they are right”. In finding no violation of Article 10, the Court underlined the significance of free speech for politicians, but also underlined the need to protect the rights of others and the importance of combatting racial discrimination..$^{58}$

In Vejdeland and Others v. Sweden (2012), the Court dealt with homophobic speech expressed in leaflets disseminated by National Youth in lockers of high school students. The leaflets held, amongst others, that homosexuality has "a morally destructive effect on the substance of society", that "HIV and AIDS appeared early with the homosexuals and that their promiscuous lifestyle was one of the main reasons for this modern-day plague gaining a foothold" and that "homosexual lobby organisations are also trying to play down pedophilia". This was the first case involving homophobic speech which was brought to Strasbourg and the Court mobilized on this opportunity to, consciously or unconsciously, rectify the gaps left by international and European legislation in terms of the hierarchy of hate described above. In this sphere, it underlined that "discrimination based on sexual orientation is as serious as discrimination based on race, origin or colour". ${ }^{59}$ The ECtHR found no violation of Article 10 and noted that "although these statements did not directly recommend individuals to commit hateful acts, they are serious and prejudicial allegations", ${ }^{60}$ and underlined that incitement to hatred does not necessarily entail a call for violence. ${ }^{61}$ Therefore, in terms of thresholds, it is clear that the ECtHR endorses a lower threshold than the EU's Framework Decision on Racism and Xenophobia since speech does not have to constitute a call for violence or hatred, but can be simply prejudicial, recognising the harm in speech itself. This approach and

\footnotetext{
57 Ibid., para. 69.

58 Le Pen v. France, App. no. 187788/09 (ECHR, 20 April 2010), para. 1.

59 Vejdeland and Others v. Sweden, App. no. 1813/07 (ECHR, 9 February 2012), para. 55.

60 Ibid., para. 54.

61 Ibid., para. 55.
} 
threshold are closest to those found in Article 4 of the ICERD, which prohibits the mere dissemination of racist ideas and beliefs.

In Balsyte-Lideikiene v. Lithuania (2009), the applicant was the founder and owner of a company which published the Lithuanian Calendar 2000. The applicant argued that her Article 10 rights had been violated after she received an administrative warning for statements contained in the calendar. Statements included, amongst others: "The soviet occupying power, with the help of the communist collaborators, among whom, in particular, were many Jews, for half a century ferociously carried out the genocide and colonisation of the Lithuanian nation". The ECtHR found that these statements incited hatred against Poles and Jews and could be deemed a serious concern for the Lithuanian authorities. ${ }^{62}$ As a result, the Court gave Lithuania a wide margin of appreciation to tackle the case in the chosen way. ${ }^{63}$ As a result, the Court found no violation of Article 10.

In sum, the Court has faced allegations of Article 10 violations by applicants who have been found to violate free speech boundaries on the national level. The Court has used this opportunity to conceptualise the limits of Article 10 and the thresholds that need to be met for speech to constitute the, albeit undefined by it, phenomenon of hate speech. Although the above list of cases is indicative of the general approach adopted by the Court to hate speech cases, it must be noted that revisionist and negationist speech have been habitually dealt with under Article 17, both by the Commission and the Court. In relation to this type of speech, the ECtHR seems to offer a high level of protection to its victims by enforcing Article 17 and, therefore, preventing any consideration of Article 10. Such cases range from older cases dealt with such as Remer $v$. Germany to more recent ones such as M'Bala M'Bala v. France (2015). Here, the Court enforced Article 17 in an application brought by a French comedian who invited a revisionist and negationist academic to a performance. The academic mainly denies the existence of gas chambers in concentration camps. The applicant called up an actor wearing pajamas like those worn by Jewish deportees, which also had a yellow star with the word "Jew". The actor awarded the academic a "prize for unfrequentability and insolence". The Court found that the portrayal of the Jewish deportee was done in a degrading manner and, given the position of the guest, this expression amounted to hatred and antiSemitism and a violation of the basic values of the Convention. The Court found that the expression was a blatant display of hatred and that anti-Semitism disguised as an artistic production was as dangerous as a fully-fledged and immediate attack. ${ }^{64}$

62 Balsytė-Lideikienè v. Lithuania, App. no. 72596/01 (ECHR, 4 November 2009), para. 79.

63 Ibid., para. 80.

${ }^{64}$ M'Bala M'Bala v. France, App. no. 25238/13 (ECHR, 20 October 2015), para. 39. 
As such, the speech did not fall within the framework of Article 10, and Article 17 came into force.$^{65}$ An interesting exception was Norwood v. The United Kingdom (2004), in which the Court, unconvincingly in comparison to previous case-law, chose to enforce Article 17. In this case, the applicant, a regional organiser for the British National Party (BNP), a far-right political party, displayed a large poster in the window of his flat, supplied by the BNP, with a photograph of the Twin Towers in flames, the words "Islam out of Britain - Protect the British People" and a symbol of a crescent and star in a prohibition sign. Here, the Court ousted the case from any free speech considerations through the application of its Article 10 test by enforcing Article 17 of the ECHR. More specifically, it held that:

a general, vehement attack against a religious group, linking the group as a whole with a grave act of terrorism, is incompatible with the values proclaimed and guaranteed by the Convention, notably tolerance, social peace and non-discrimination. ${ }^{66}$

As a result of its above appraisal of the impugned expression and the harm and destruction it associated therewith, it considered that the application fell outside the scope of Article 10. However, it gave no extrapolation of severity thresholds that led to the use of Article 17. Furthermore, it is unclear why Article 17 was used in Norwood, while in the later and similar cases referred to above, another approach was used, namely an evaluation of Article 10 violation allegations through an examination of the case by adopting the Article 10 test developed in Sunday Times. Interestingly, in Soulas v. France (2008), the Court made some reference to when Article 17 should be used. In this case, the applicants were the authors of a book which looked at alleged incongruences between European and Islamic cultures. The applicants were convicted by the national court for inciting hate propaganda and claimed an Article 10 violation at Strasbourg. Statements in the book included, for example, "it is only if an ethnic civil war breaks out that the solution can be found". The Court held that such statements could potentially incite aggression against the targeted group. ${ }^{67}$ As a result, it found no violation of Article 10, but held that the level of severity for the use of Article 17 was not met. ${ }^{68}$ In sum, the ECtHR has embraced a relatively low threshold in finding hate speech, as particularly reflected in Soulas. It must be noted, however, that the Court is careful in terms of the issue of proportionality. The low threshold it adopts does not equate to endorsing criminal law for all cases it confronts. In brief, "the expression of racial hatred is not covered by the protective scope of Article 10(1)" (Belavusau, 2013: 49).

65 Ibid., para. 41 and 42.

${ }^{66}$ Norwood v. The United Kingdom, App. no. 23131/03 (ECHR, 16 November 2004).

67 Soulas and Others v. France, App. no. 15948/03 (ECHR, 10 July 2008), para. 43.

${ }^{68}$ Ibid., para. 48. 


\section{Conclusion}

In conclusion, the UN framework does seek to tackle certain types of hate speech and could be considered as an important contributor to the fight against hate speech. However, the question arises as to whether its role is beyond symbolic and, more importantly, whether this framework is actually effective both conceptually and practically. To complicate matters, the thresholds associated with Article 4 of the ICERD and Article 20 of the ICCPR are different, with no explanation as to why the same framework, namely the UN, is adopting a different approach to tools which have been developed to tackle intolerance and resulting hate speech. The EU's Framework Decision incorporates higher thresholds than the UN documents, whilst the Additional Protocol finds itself somewhere in the middle of the UN and EU documents in terms of thresholds. Moreover, the ever-existing persistence of countries across the globe to attach a sacred cow status to free speech when confronted with hate speech regulation is reflected in reservations made to the UN articles and safety nets incorporated in the Framework Decision and the Additional Protocol. All above-discussed documents focus solely on speech attacking racial, ethnic and religious characteristics, with no documents or provisions protecting attacks on sexual orientation and gender identity, resulting in an arbitrary and unjustified hierarchy of hate that is deemed worthy of legal address on an international and European scale. The ECtHR has partly tackled this loophole in Vejdeland by stipulating that homophobic speech is just as damaging as racist speech. Moreover, for purposes of ensuring an all-encompassing approach to hate speech regulation, both the EU and the Council of Europe should incorporate provisions and documents dealing with the use of non-criminal legislative measures to tackle hate speech which may not reach the threshold needed for the use of criminal law but may cause harm.

\section{REFERENCES}

ARTICLE 19. 2010. Towards an Interpretation of Article 20 of the ICCPR: Thresholds for the Prohibition of Incitement to Hatred: Work in Progress - A Study Prepared for the Regional Expert Meeting on Article 20. The Office of the High Commissioner for Human Rights, available at: http://www.ohchr.org/Documents/Issues/Expression/ICCPR/Vienna/CRP7Callamard.pdf (accessed 8 December 2017).

ARTICLE 19. 2013. Policy Brief - Responding to Hate Speech against LBGTI People.

Banks, James. 2010. Regulating Hate Speech Online. International Review of Law, Computers and Technology, (24) 3:233-239. 
Belavusau, Uladzislau. 2013. Freedom of Speech: Importing European and US Constitutional Models in Transitional Democracie (1st ed.). Routledge. London.

Buyse, Antoine. 2014. Dangerous Expression: the ECHR, Violence and Free Speech. International and Comparative Law Quarterly, (63) 2: 491-503.

Kiska, Roger. 2012. Hate Speech: A Comparison Between The European Court of Human Rights and the United States Supreme Court Jurisprudence. Regent University Law Review, (25): 107-151.

McGonagle, Tarlach. 2013. The Council of Europe against Online Hate Speech: Conundrums and Challenges. Expert Paper. Belgrade: Ministry of Culture and Information, available at: http://hub.coe.int/c/document_library/get_file?uuid=62fab806724e-435a-b7a5-153ce2b57c18\&groupId=10227 (accessed 20 December 2017).

Tulkens, Françoise. 2013. The Hate Factor in Political Speech. Where Do Responsibilities Lie? Available at: https://rm.coe.int/16800c170e (accessed 15 March 2018).

\section{European and International Documents}

CERD Concluding Observations: United States of America, 2001 (CERD/C/59/Misc. 17/Rev. 3).

CERD General Recommendation 1: States Parties' Obligations, 1972 (A/8718 at 37).

CERD General Recommendation 15: Measures to Eradicate Incitement to or Acts of Discrimination, 1994 (A/48/18 at 114).

CERD General Recommendation 31: The Prevention of Racial Discrimination in the Administration and Functioning of the Criminal Justice System, 2005 (A/60/18).

CERD General Recommendation 32: The Meaning and Scope of Special Measures in the Convention, 2009 (CERD/C/GC/32).

CERD General Recommendation 35: Combatting Racist Hate Speech, 2013 (CERD/C/ $\mathrm{GC} / 35$ ).

CERD Concluding Observations: Japan, 2014 (CERD/C/JPN/CO/7-9).

Council of Europe's Committee of Ministers Recommendation, 1997: 97 (20) on Hate Speech.

European Parliament: Motion for a European Parliament resolution on establishing a common legal definition of hate speech in the EU, 2017.

European Parliament: Resolution on the EU Roadmap against homophobia and discrimination on grounds of sexual orientation and gender identity, 2014 (2013/2183(INI).

Explanatory Report to the Additional Protocol to the Convention on Cybercrime, concerning the Criminalisation of Acts of a Racist and Xenophobic Nature committed through Computer Systems, 2003.

General Assembly Resolution 66/143: Inadmissibility of certain practices that contribute to fuelling contemporary forms of racism, racial discrimination, xenophobia and related intolerance, 2012. 
Human Rights Council Resolution 16/18: Combating intolerance, negative stereotyping and stigmatization of, and discrimination, incitement to violence, and violence against persons based on religion or belief, 2011.

Human Rights Committee General Comment 11: Article 20 - Prohibition of Propaganda for War and Inciting National, Racial or Religious Hatred, 1994 (HRI/GEN/1/Rev.1 at 12).

Human Rights Committee General Comment 34: Article 19 - Freedom of Opinion and Expression, 2011 (CCPR/C/GC/34).

Rabat Plan of Action on the Prohibition of Advocacy of National, Racial or Religious Hatred that Constitutes Incitement to Discrimination, Hostility or Violence, 2002.

Report of the Special Rapporteur on the Promotion and Protection of the Right to Freedom of Opinion and Expression, 2012 (A/67/357).

\section{Case-law}

ECtHR

Balsytè-Lideikienè v. Lithuania, Application no.72596/01 (4 November 2009).

Féret v. Belgium, Application no. 15615/07 (10 December 2009).

Erbakan v. Turkey, Application no. 59405/00 (6 July 2006).

Gündüz v. Turkey, Application no. 35071/97 (4 December 2003).

Le Pen v. France, Application no. 187788/09 (20 April 2010).

Vejdeland and Others v. Sweden, Application no. 1813/07 (09 February 2012).

$U N$

Adan v. Denmark, Communication no. 43/2008, CERD/C/77/D/43/2008 (13 August 2010).

Faurisson v. France, Communication no. 550/1993, CCPR/C/58/D/550/1993 (8 November 1996).

Gelle v. Denmark, Communication no. 34/2004, CERD/C/68/D/34/2004 (15 March 2006).

Jama v. Denmark, Communication no. 41/2008, CERD/C/75/D/41/2008 (21 August 2009).

L.K. v. The Netherlands, Communication no. 4/1991, A/48/18 (16 March 1993).

Rabbae, A.B.S and N.A v. The Netherlands, Communication no. 2124/2011 (18 November 2016).

TBB-Turkish Union v. Germany, Communication no. 48/2010, CERD/C/82/D/48/2 (4 April 2013).

Toonen v. Australia, Communication no. 488/1992, CCPR/C/50/D/488/1992 (31 March 1994). 
Yilmaz-Dogan v. The Netherlands, Communication no. 1/1984, CERD/C/36/D/1/1984 (10 August 1988).

Zentralrat Deutscher Sinti und Roma et al. v. Germany, Communication no. 38/2006, CERD/C/72/D/38/2006 (3 March 2008).

Mailing Address: Natalie Alkiviadou, School of Law, University of Central Lancashire Cyprus, 12-14 University Avenue Pyla, 7080 Larnaka, Cyprus. E-mail: nalkiviadou@uclan.ac.uk 